\title{
TRADICIÓN ESPIRITUAL Y AUTORIDAD EN EL LIBRO LLAMADO ABECEDARIO ESPIRITUAL DE FRANCISCO DE OSUNA
}

\author{
POR \\ RAFAEL M. PÉREZ GARCÍA ${ }^{1}$ \\ Universidad de Sevilla
}

RESUMEN

Este artículo estudia el proceso de composición del Libro llamado Abecedario espiritual de Francisco de Osuna en el contexto del conflicto entre las doctrinas del recogimiento y del dexamiento en el seno de la provincia franciscana de Castilla durante la década de 1520. Para ello, se analiza el uso dado a la Biblia, el método teológico empleado y el sistema de autoridades construido para defender el texto mediante la identificación de la doctrina del recogimiento con la teología mística de la tradición eclesiástica.

PALABRAS CLAVE: Francisco de Osuna; Abecedario espiritual; literatura mística; recogimiento; alumbrados.

\section{SPIRITUAL TRADITION AND AUTHORITY IN THE LIBRO LLAMADO ABECEDARIO ESPIRITUAL OF FRANCISCO DE OSUNA}

\begin{abstract}
During the 1520 s, a theological controversy about the prayer took place in relationship with the franciscan province of Castile. Two different doctrines, the Dexamiento and the Recogimiento, were involved in that dispute. Francisco de Osuna wrote and published his Libro Ilamado Abecedario espiritual in that historical context. This article studies his theological and biblical methodology, as well as the system of theological authorities used by Osuna in order to explain that Recogimiento was the mystical theology taught by ecclesiastical tradition.
\end{abstract}

KEY WORDS: Francisco de Osuna; Spiritual Alphabet; mystical literature; mystic of withdrawal; alumbrados.

CÓMO CITAR ESTE ARTículo / CITATION: Pérez García, Rafael M. 2021. «Tradición espiritual y autoridad en el Libro llamado Abecedario espiritual de Francisco de Osuna». Hispania Sacra LXXIII, 148: 389-402. https://doi.org/10.3989/hs.2021.030

Recibido/Received 11-05-2020

Aceptado/Accepted $\quad 09-12-2020$

\section{INTRODUCCIÓN}

Publicado en la ciudad de Toledo en 1527, el Tercer Abecedario Espiritual del franciscano Francisco de Osuna ha sido valorado de manera continuada por la crítica desde comienzos del siglo XX hasta el presente como una obra clave en la historia de la mística y de la literatura mística en España. Ello se debe fundamentalmente al papel que desempeñó en la formación espiritual de Santa Teresa de Jesús, quien lo leyó y aprendió de él como si de un maestro se tratase. ${ }^{2}$ En las últimas décadas, los estudios de Mel-

\footnotetext{
1 rperez4@us.es / ORCID iD: https://orcid.org/0000-0002-35585104

2 Revisión del tema en Pérez García 2018. Abreviaturas utilizadas: AGS=Archivo General de Simancas; $\mathrm{AHN}=$ Archivo Histórico Nacional
}

quiades Andrés Martín han convertido al Tercer Abecedario, en tanto que primera codificación impresa y conocida de la mística del recogimiento, en una clave interpretativa fundamental para la historia de la mística española, ${ }^{3}$ permitiendo superar los paradigmas tradicionales que hicieron girar a esta primero sobre la propia figura de Santa Teresa y después sobre la recepción en España de las obras de Erasmo de Rotterdam, según la exitosa interpretación de Marcel Bataillon en su Érasme et l'Espagne de $1937 .{ }^{4}$ Los precisos estudios publicados desde mediados del siglo XX sobre los

\footnotetext{
(Madrid); $\mathrm{AHNo=Archivo} \mathrm{Histórico} \mathrm{de} \mathrm{la} \mathrm{Nobleza} \mathrm{(Toledo);} \mathrm{CC=Cámara}$ de Castilla; I=Inquisición.

3 Andrés Martín 1994 y 1975.

4 Pérez García 2018 y 2009a.
} 
procesos de reforma de las órdenes religiosas en la península Ibérica, ${ }^{5}$ y especialmente de la orden franciscana, que arrancaron en los últimos años del siglo XIV y se extendieron hasta los días mismos de Osuna, ${ }^{6}$ han permitido comprender mejor el proceso histórico de escritura de la literatura mística en España. ${ }^{7}$ El Tercer Abecedario es un resultado de aquel concreto contexto de reforma religiosa que se vivía en el franciscanismo. Pero además es necesario recordar que la publicación de la obra se produjo en relación directa con las actuaciones inquisitoriales que se llevaron a cabo contra los llamados alumbrados del reino de Toledo en la década de $1520,{ }^{8}$ como ya señalara hace mucho tiempo Fidèle de Ros. ${ }^{9}$ En este artículo se estudia el efecto de aquel contexto histórico concreto en la redacción definitiva del texto del Tercer Abecedario Espiritual que fue llevado a la imprenta en $1527 .{ }^{10}$

\section{LA CRISIS DE LOS ALUMBRADOS DEL REINO DE TOLEDO Y LA PUBLICACIÓN DEL LIBRO LLAMADO ABECEDARIO ESPIRITUAL}

Francisco de Osuna debió iniciar la redacción de sus tres primeros Abecedarios espirituales hacia 1520, quizás un poco antes, cuando vivía como fraile en el convento de Nuestra Señora de la Salceda, centro fundamental del reformismo franciscano del siglo anterior. En los años siguientes, Osuna y otros frailes de La Salceda y de la región, entre los que se contaba fray Francisco Ortiz, se dedicaron a un intenso apostolado espiritual a lo largo de un extenso territorio ubicado en el corazón de España, enseñando la doctrina mística del recogimiento en los principales núcleos de población del espacio correspondiente a la provincia franciscana de Castilla, así en Cifuentes, Pastrana, Guadalajara, Alcalá de Henares, Madrid, Toledo, Escalona y Torrijos. No obstante, en el seno de dicha provincia surgieron importantes desavenencias acerca de la oración, que tomaron forma en la que se llamó doctrina del dexamiento, crítica con el recogimiento, y también propuesta por otros frailes franciscanos que la enseñaron a grupos de laicos que la acabaron adoptando. Estos últimos comenzaron a ser investigados por la Inquisición de Toledo en 1524 y al año siguiente este tribunal promulgó un edicto contra ellos, denominándolos alumbrados o dexados. ${ }^{11}$ En 1529 sus principales líderes,

5 Entre otros: García Oro 1980; Beltrán de Heredia 1939 y 1941; Colombás 1955; Álvarez 1978; Martínez Cuesta 1995, 1: 138-187; Nieva Ocampo 2006 y 2009.

Uribe y Lejarza 1957; Lejarza 1962; Uribe 1962; Meseguer 1961; Andrés Martín 1988.

Pérez García 2014 y $2006 a$.

8 Pérez García 2006b, 179-183.

Ros 1936, 77-105.

10 Al esfuerzo de Osuna para diferenciar su propia doctrina de la de los alumbrados de Toledo, se ha referido ya Andrés Martín (1981), tratando del tema del amor en el Cuarto Abecedario espiritual, y de forma más genérica en Andrés Martín (1977). La cuestión reaparece en Garbay-Velázquez 2013a y 2018.

11 Los términos recogimiento y recogido, dexamiento y dexado, así como alumbrado, son términos históricos que fueron empleados por las personas e instituciones que tomaron parte en los hechos aquí estudiados. Para notar su especificidad, y en algunos casos la diferencia, identidad o relación entre ellos, en ocasiones aparecerán en cursiva a lo largo de este artículo. Asimismo, para insistir en su historicidad se han conservado las formas arcaizantes dexamiento y dexado. En este estudio, dedicado a la obra de Osuna, los términos recogimiento y recogido son empleados según los significados que él mismo les otorgó y explicó entre los que se contaba Pedro Ruiz de Alcaraz, fueron condenados en un auto de fe. La crisis vivida sacudió profundamente a la provincia franciscana de Castilla, pues también algunos de sus frailes fueron procesados y castigados.

cuidadosamente. Por supuesto, Osuna no es el creador de estos términos, ni tampoco el único que los empleó, pues su uso estaba extendido en los ambientes espirituales del territorio de la provincia franciscana de Castilla en que tuvieron lugar los acontecimientos que aquí se tratan; una detallada y documentada exposición de ellos, en que se apoya este trabajo, en Pérez García 2005a, 123-244. Fueron precisamente los franciscanos de esta provincia quienes difundieron los términos recogimiento y recogido durante su apostolado espiritual y por ello los encontramos también en algunas deposiciones conservadas en los procesos inquisitoriales contra fray Francisco Ortiz y Pedro Ruiz de Alcaraz (Selke 1968, 231-249, vid infra también). Resultan relevantes las declaraciones relativas a lo sucedido en Pastrana, donde Osuna y otros frailes explicaron la práctica y doctrina del recogimiento, como sabemos por las declaraciones a la Inquisición de las mismas personas que habían sido enseñadas por el franciscano. En Pastrana tuvo lugar en 1522-1523 un enfrentamiento frontal entre los seguidores del recogimiento y los del dexamiento, una práctica de la oración llegada allí desde Guadalajara (por la enseñanza de la terciaria franciscana Isabel de la Cruz y de Pedro Ruiz de Alcaraz) y desde Cifuentes, de la mano de franciscanos dexados como fray Diego de Barreda y fray Antonio de Pastrana: según un testigo, estos dos enseñaban en Cifuentes «que era mejor e más çierto camino el del dexamiento que no el del recogimiento». Es necesario considerar que ambas doctrinas entraron en conflicto en el seno de la provincia franciscana de Castilla, y que su conceptualización y aplicación en la práctica espiritual es previa a la intervención de la Inquisición contra los que después fueron calificados de alumbrados del reino de Toledo (Pérez García 2005a, 171-189; Selke 1968, 231-247; Serrano y Sanz 1903, 7; véase también la interpretación de Bataillon 1966, 169). Por su parte, el término alumbrado en la lengua castellana del siglo XV, cuando se comienza a escribir de teología espiritual en este idioma romance, carecía de cualquier connotación negativa o herética, todo lo contrario. Fue el edicto inquisitorial de Toledo de 1525 el que convirtió el término alumbrado en una categoría heresiológica en el ámbito territorial de Castilla y en la lengua castellana, transformando radicalmente su significado al asociarlo a una serie de proposiciones que, según el edicto, habrían sido defendidas por "algunos» que "se dezían alumbrados e dexados o perfectos»: de esta manera el término alumbrado se asoció semánticamente con la doctrina del dexamiento (el texto del edicto publicado en Márquez 1980, 229-238; para su comprensión, Ortega Costa 1977). Sirva esta aclaración para comprender el empleo que hacemos de esta serie de términos respetando sus significados históricos. La no observancia de este principio hermenéutico elemental ha provocado una enorme confusión en la historiografía, especialmente desde que Bataillon diera a luz el concepto «iluminismo» para referirse a la doctrina de los «alumbrados, dejados o perfectos» mencionados en el edicto inquisitorial de 1525 , y pasase a definirlo no sobre la base de dicho edicto o la información contenida en los procesos inquisitoriales correspondientes, sino de una manera vaga que ha hecho fortuna: «El iluminismo español es, en sentido amplio, un cristianismo interiorizado, un sentimiento vivo de la gracia» (Bataillon 1966, 166-167). A partir de aquí, Bataillon dedicó algunas páginas a mostrar las diferencias y similitudes entre el recogimiento y el dejamiento. Las fuentes que empleó para ello fueron, sin embargo, escasas, aparte de demostrar un conocimiento ciertamente superficial del Tercer Abecedario; para el dejamiento, apenas dispuso del edicto de 1525, del proceso contra Francisco Ortiz al que accedió de manera indirecta a partir del libro de Boehmer (1865), y de los fragmentos del proceso de Alcaraz contenidos en el artículo de Serrano y Sanz (1903), donde por primera vez se daban noticias coherentes sobre el mismo (Bataillon 1966, 166-176). Años más tarde, Bataillon reconoció que no había leído el proceso de Alcaraz cuando escribió Erasmo y España (Bataillon 2000, 251). Este débil conocimiento de las fuentes históricas explica las conclusiones a las que llega, creyendo incluso haber demostrado que «recogidos» y "dejados» no están en desacuerdo violento», y esforzándose por mostrar similitudes entre ellos. Sus conclusiones denotan además falta de comprensión del carácter dogmático de la teología católica. Después de Bataillon, el uso arbitrario del término «iluminismo» para referirse a los alumbrados o a cualquier persona o grupo calificable de espiritual, ha inundado de confusión buena parte de la producción historiográfica. 
En ese contexto, Francisco de Osuna sintió la necesidad de clarificar su posición sobre la oración y perfilar la doctrina del recogimiento, para deslindarla con claridad del dexamiento. Para ello, en la Tercera parte del libro llamado Abecedario espiritual (el Tercer Abecedario Espiritual) se esforzó en explicar que el recogimiento no era sino la teología mística de la tradición de la Iglesia. Dado que de aquel Libro llamado Abecedario espiritual, cuyas tres partes se corresponden con los tres famosos primeros Abecedarios, existían versiones que corrían manuscritas y, según el mismo Osuna, ${ }^{12}$ habían sido ampliadas y comentadas por manos extrañas con añadidos que deformaban su propia intención, nuestro franciscano decidió completar su texto y fijarlo de manera definitiva. ${ }^{13}$ Para ello era fundamental darlo a la imprenta, consiguiendo tanto la autorización de las autoridades de la provincia franciscana de Castilla como un privilegio de impresión del Consejo Real de Castilla. Dado que era la doctrina del recogimiento la que urgía defender, fue la Tercera parte del libro llamado Abecedario espiritual, en la que aquella era tratada, la primera en ser publicada, y así sucedió en Toledo en 1527; no es casualidad que tanto en la portada como en el colofón de esta primera edición del Tercer Abecedario Espiritual se hiciera constar el hecho de que se imprimía en virtud de un privilegio imperial otorgado por el mismísimo Emperador Carlos $\mathrm{V}^{14}$. Tras estos acontecimientos, Osuna marchó a Sevilla, donde publicó en 1528 la Primera parte del libro llamado Abecedario espiritual, y, en 1530, la Segunda parte del libro llamado Abecedario espiritual. ${ }^{15}$ La denominación de Primera, Segunda y Tercera partes "del libro llamado Abecedario espiritual», que aparece en las portadas de las tres obras, unido al hecho de que al comienzo de la Primera parte Osuna incluyera «el prólogo primero que habla sobre las tres partes del Libro llamado Abecedario Spiritual», ${ }^{16}$ indican con claridad que, como además se explicita en este prólogo, las tres obras fueron concebidas por su autor como un único conjunto. De ello se deriva su denominación compartida de Libro llamado Abecedario espiritual, creada y usada por el propio Osuna y que se seguirá en este trabajo. Este hecho explica la perspectiva metodológica adoptada en esta investigación de estudiar el Tercer Abecedario Espiritual en el seno del Libro llamado Abecedario espiritual.

\section{AUTORIDAD, MÉTOdO TEOLÓGICO Y BIBLIA EN EL LIBRO LLAMADO ABECEDARIO ESPIRITUAL}

La composición definitiva de los tres primeros Abecedarios espirituales de Francisco de Osuna se vio profundamente condicionada por el contexto que acabamos de presentar. Su estructura ha sido descrita en ocasiones como desordenada y falta de sistematicidad. ${ }^{17}$ Esta valoración sería ajustada si nos encontrásemos ante un tratado escolástico, pero

12 Osuna 2004a, 126.

13 Sobre esta circulación manuscrita, Garbay-Velázquez $2013 b$.

14 La copia original de este privilegio por ocho años, otorgado en Granada el 31 de agosto de 1526, se conserva en AGS: CC, libro de cédulas 75, ff. 290r-291r.

15 Para todo lo anterior, Pérez García 2006b, 179-185, 310-314, 355, y Pérez García 2005a, 123-241, especialmente 173-206 y 226-232.

16 Osuna 2004a, 123-130.

17 Groult 1976, 1: 139-140. no es el caso, puesto que dicha arquitectura guarda relación con el carácter práctico que adopta el Libro llamado Abecedario Espiritual como texto de guía espiritual. En efecto, los tres Abecedarios que lo componen están pensados para acompañar al devoto por los caminos del espíritu, y a este objetivo se ordenan tanto su estructura alfabética de finalidad nemotécnica y estética, que rompe deliberadamente todo intento de acercamiento sistemático racional a la materia, como la omnipresencia de la alegoría y el simbolismo, los abundantes recursos nemotécnicos, las imágenes claras y deslumbrantes, ${ }^{18}$ los juegos de palabras y refranes, ${ }^{19}$ así como los ejemplos e historias que atraviesan constantemente el texto. ${ }^{20}$

Los tres primeros Abecedarios contienen tres series de 23 ejercicios espirituales cada una: la primera vinculada a «el ejercicio de la sacra Pasión» y la tercera a la "vía del recogimiento ${ }^{21} \mathrm{o}$ "vía negativa " $^{22}$ o teología mística, ${ }^{23}$ que ocupa el lugar tercero precisamente por su significación numerológica de perfección y plenitud; ${ }^{24}$ si bien la serie contenida en el Segundo Abecedario presenta ciertamente un conjunto misceláneo de ejercicios espirituales, Osuna no oculta su pretensión de considerarla como un estadio intermedio, aunque de hecho su propuesta pivote sobre dos vías, frecuentemente enunciadas de forma complementaria, la de "los que piensan la sacra pasión» y la de los que siguen el recogimiento. ${ }^{25}$ La triple organización guarda a su vez relación con los tres grados de progresión en la vida espiritual, a saber, principiantes, aprovechantes y perfectos, ${ }^{26}$ según la división clásica originada en la teología alejandrina y transmitida de forma común y continuada en la tradición espiritual, desde Orígenes y san Gregorio de Nisa a san Bernardo de Claraval, san Buenaventura y numerosos autores espirituales medievales. Esta concepción tripartita la traslada Osuna al desarrollo mismo de la práctica espiritual, de modo que, por ejemplo, los tres tratados décimos de cada uno de los tres primeros Abecedarios, correspondientes a la letra $L$, se dedican a las lágrimas, con la única diferencia

18 Sobre las imágenes, Ros 1936, 405-410; Calvert 1973; Pérez García 2005b.

19 Ros 1936, 411-412.

20 Pérez García 2009b.

21 Osuna 1998, 390.

22 Ibídem, 144. Evidentemente, está remitiendo directamente al capítulo III de la Teología mística del Pseudo Dionisio Areopagita.

23 Osuna 1998, 199-203.

24 «... el lugar tercero que a las más perfectas sentencias se presume reservado. A esto se responde que en todas las cosas hay principio y medio y fin, y en cada ejercicio hay principiantes y aprovechantes y perfectos, así en las cosas de naturaleza como de arte y gracia. Si miras en ello, verás yerba y espiga y grano» (Osuna 1998, 177). Al expresarse de esta manera, Osuna se inserta plena y conscientemente en la tradición del simbolismo numerológico, de raíces semitas y griegas, recibida por los Padres de la Iglesia y transmitida en la literatura eclesiástica. Como explica de Lubac: "Trois, nous l'avons dit, est véritablement le nombre premier, parce qu'il est le premier «qui ait ligature»; il est le premier nombre organisé, comportant commencement, milieu et fin, unis en un seul tout, dans une égalité parfaite: «In ternario numero quamdam esse perfectionem, quia totus est; habet enim principium, medium et finem ", cita que procede de san Agustín (Lubac 1993, 4: 25).

25 Osuna 1998, 522, 390 y 523. Posiblemente con la división en tres Abecedarios y no en dos también se están queriendo evitar las connotaciones negativas asociadas a este último número (Lubac 1993, 4: 13-15).

26 Osuna 1998, 177-178. 
de que el tratamiento de estas se encuentra graduado en función de cada uno de los tres estadios del progreso espiritual. ${ }^{27}$

Hay además otra razón fundamental que explica la naturaleza de la redacción y composición de los tres Abecedarios que estudiamos, y está vinculada con un modo tradicional de hacer teología, ${ }^{28}$ de honda raíz bíblica y que no sigue en su estructura general la arquitectura lógica propia del método escolástico, aunque sí aproveche en ocasiones conceptos, disputas, argumentaciones y materiales varios que son insertados dentro de la propia estructura alfabética de los Abecedarios. Se trata del método propio de la teología espiritual que busca conducir al devoto al encuentro con Dios por la vía del amor, y que se enraíza en la lectura de la Escritura interpretada a la luz de los cuatro sentidos tradicionales, ${ }^{29}$ leyendo el Antiguo Testamento como figura del Nuevo, ${ }^{30}$ y buscando despertar el afecto y no el entendimiento del lector. ${ }^{31}$ Es decir, el propio método expositivo de los Abecedarios, que es el de la teología espiritual y no el de la escolástica, reproduce fielmente una teoría del conocimiento y de la lectura en la que las facultades analíticas del lector (las propias del conocimiento habitual) son consideradas solo como instrumentales y están llamadas a cesar en su funcionamiento en un momento preciso del proceso de progresión espiritual en tanto que se persigue en última instancia la activación de las facultades habitualmente dormidas (la inteligencia en el vocabulario espiritual de los victorinos) del conocimiento no habitual, el que se produce únicamente por amor y gracia. ${ }^{32}$ Ello es así especialmente en el Tercer Abecedario, que quiere mover la voluntad y los

27 El tratado décimo del Primer Abecedario «Habla de las preciosas lágrimas del Señor, diziendo: «Las lágrimas no se olviden pues todos sus miembros lloran», mientras que el del Segundo Abecedario «Te amonesta llorar la Passión y vencer cautelosamente los engaños del demonio, diziendo: "Llorar deves la Passión y engañar las ocasiones" ", y el del Tercer Abecedario "Habla de las lágrimas del recogimiento, y dice: "Lágrimas sean tus armas por la gracia peleando"». El mismo Osuna se refiere en el Tercer Abecedario a que los justos «lloran unas lágrimas muy de otra manera que las del Segundo Abecedario» (Osuna 1998, 299).

28 Cf. Leclerq 1964.

29 Pérez García 2010, 161-168. A los sentidos literal, espiritual y anagógico se refiere explícitamente el propio Osuna en Primer Abecedario (Osuna 2004a, 231, 525); un análisis según los sentidos literal y anagógico en ibídem, 231, y referencia al "místico sentido» (ibídem, 553) y al "sentido alegórico» (Osuna 1998, 126). Osuna llegará incluso a explicar detenidamente los cuatro sentidos de la Escritura en el Sexto Abecedario (Osuna 2002, 961-962, 1078-1080). Véase también Ros 1936, 377-378, 396-397.

30 Pérez García 2010, 164-168; Lubac 1993, 4: 60-84, sobre el tema «Omnia in figura». Groult, que se daba cuenta de que «Esta interpretación de la Biblia no es sino la aplicación de un sistema alegórico más general, muy extendido, como es sabido, en los Padres», ofrece una valoración ciertamente despectiva: «su erudición es, simplemente, fastidiosa. No tiene nada de verdadera ciencia, es un malabarismo de los textos sagrados» (Groult 1976, 1: 142-143).

31 En el capítulo VII del tratado 16 del Tercer Abecedario, titulado "Cómo has de sacar amor de la Escritura Sagrada», el mismo Osuna hace el ejercicio de exponer el Decálogo desde el sentido espiritual y procediendo a una «espiritual y amorosa declaración» de los diez mandamientos (Osuna 1998, 438-441); en el capítulo siguiente, el octavo, continúa con la misma práctica exegética y «declara amorosamente la oración del Pater Noster» (Osuna 1998, 441-446).

32 Pérez García 2005a, 388-422; Illich 2002. Análisis de la estructura del alma en la psicología de Osuna, en Ros 1936, 481-488; y del recogimiento en Ros 1936, 488-502. afectos, no la razón ni el entendimiento. Por eso están escritos de esa forma. La estructura alfabética, por su parte, es justificada por Osuna también basándose en la Biblia. ${ }^{33}$

Y porque quieren conducir al encuentro con Dios, todo en los Abecedarios no es sino un continuado deambular por la Escritura, Ilamada por Osuna «la carta del marear». ${ }^{34}$ Sus personajes, topónimos, expresiones e historias se transforman así en un bosque de lugares plenos de conocimientos y significados ocultos que precisan ser desvelados. El misterio de Dios está encerrado en el texto bíblico, y por ello la teología espiritual, que busca conocer por amor a un Dios espiritual, solo puede ser bíblica. Cualquier persona que se acerque a las tres primeras partes del Libro llamado Abecedario espiritual se percatará enseguida de que sus 638 folios en formato 4으 no son sino un febril recorrido por la historia sagrada en la que el lector es inducido una y otra vez a encontrarse con Dios a través del desvelamiento de innumerables sentidos figurados y mensajes ocultos. Rara es la página que no contenga varias citas o referencias a las Sagradas Escrituras. Gracias a esos miles de pasajes, ejemplos y figuras de la Biblia, el lector es introducido en el sentido espiritual de la realidad, en una manera diferente de leer y ver que trasciende el sentido literal de la Escritura y el orden material de las cosas asequible habitualmente por el método especulativo.

Así, los Abecedarios son también una gigantesca exposición de la Biblia, pero ello solo se hace evidente al lector que los ha rumiado durante mucho tiempo, ${ }^{35}$ absorbiendo en su memoria los innumerables juegos de significados que, a pesar del aparente caos, guardan en todo momento su coherencia desde la perspectiva de la exégesis simultánea que recurre a los diferentes sentidos de la Escritura. Sin embargo, Osuna huye de cualquier pretensión personalista en la interpretación de la misma. Él no se considera sino un maestro espiritual que pretende contribuir a mostrar una sabiduría de la que solo es transmisor, nunca creador, y que se inserta constitutivamente en la propia tradición y enseñanza de la Iglesia. ${ }^{36}$ Este criterio, que el mismo Osuna recordará en algunos pasajes, ${ }^{37}$ se expresa en el recurso continuado a las glosas tradicionales que habían acompañado durante siglos al texto de la Biblia. Las referencias a "la glosa», a "una glosa» o a "las glosas» son frecuentes, ${ }^{38}$

33 En el prólogo al Libro llamado Abecedario espiritual, escribe: «E quíselos compilar por abecé y en número ternario por imitar a Jeremías, y al sabio Salomón y al rey David, los quales solos en la Sagrada Escritura se halla aver escripto por abecedario en cierta manera de metros que entonces se usava començando ordenadamente por las letras del abecé» (Osuna 2004a, 124). Sobre los abecedarios en la tradición literaria y espiritual, Quirós 1997 y 1998.

34 Osuna 1998, 182.

35 Como Santa Teresa de Jesús cuenta en el Libro de la vida (1997, 42-43).

36 Como apuntó acertadamente Lubac 1993, IV: 498. Osuna lo expresa a su manera en el prólogo del Libro llamado Abecedario espiritual: «... allegué y junté tres Alphabetos o Abecedarios para mi provisión, y si alguno dixere ser de las mieses agenas, como de mío ninguna cosa tenga, fácilmente se lo concederé no tomándolo por injuria» (Osuna 2004a, 123).

37 Osuna 2002, 1127-1128.

38 Entre otras muchas, en el Primer Abecedario, Osuna 2004a, 231 («según el sentido literal que las glosas declaran»); en el Segundo Abecedario, Osuna 2004b, 241, 541 ("Sobre lo qual dize la glosa», "Y la glosa dize», "Sobre esto dize la glosa», que corresponden las dos primeras a la glosa interlineal y la última a la ordinaria); o Tercer Abe- 
mencionándose además explícitamente tanto la glosa ordinaria ${ }^{39}$ como la glosa interlineal, ${ }^{40}$ además de usar, por supuesto, los comentarios de Nicolás de Lira, que también se esconden muchas veces bajo simples menciones a "según dize la glosa». ${ }^{41}$ En obras posteriores emergen también referencias explícitas a los comentarios de Nicolás de Lira, ${ }^{42} \mathrm{~Pa}$ blo de Santa María (el Burgense) ${ }^{43}$ y Mathias Doering. ${ }^{44}$ Por ello, no cabe duda de que la fuente esencial de Osuna era la Biblia y de que su principal instrumento de trabajo era la Biblia sacra cum glossis interlineari et ordinaria, Nicolai Lyrani postilla et moralitatibus, Burgensis additionibus et Thoringi replicis, cuyas numerosas ediciones lyonesas y parisinas no solo circulaban por España sino que no faltaban en las bibliotecas de los conventos franciscanos castellanos. ${ }^{45}$

Por supuesto, Osuna se vale también de un buen número de comentaristas bíblicos de su tiempo, a los que cita en sus libros latinos: el franciscano italiano Pietro Galatino, el carmelita inglés Alanus Linensis, el franciscano irlandés Mauritius O'Fihely, el francés Lefèvre d'Étaples. Entre ellos destaca Galatino, cabalista cristiano en el que, según Ros, Osuna descubre numerosas etimologías y alegorías bíblicas. ${ }^{46}$

Osuna recurre asimismo a la comparación entre traducciones para su trabajo exegético; así, por ejemplo, tras explicar el significado de Salmos 84,9, añade: «Otra traslación dice en este lugar: ... ${ }^{47}$ y tras comentar Salmos 41,3-4, de nuevo para apuntalar su interpretación, escribe: «Y que este tornar sobre sí se fundase en el recogimiento del ánima parece a la clara por la traslación de san Jerónimo, que dice...". ${ }^{48} Y$ el pasaje del profeta Oseas 13,6-8 lo incorpora en su texto "según la translación de los Setenta». ${ }^{49}$ Aunque seguimos careciendo de un estudio preciso sobre las diferentes versiones de la Biblia usadas por Osuna, todo parece indicar que también se valió de una Biblia políglota complutense.

De la Biblia sacra cum glossis, Francisco de Osuna no solo extraía las glosas con su sentir tradicional, sino innumerables autoridades que son citadas a partir de ellas. Así sucede, por ejemplo, con san Jerónimo ${ }^{50}$ o san Agustín, en-

cedario, Osuna 1998, 451 («como la glosa declara»), 463 («Sobre lo cual dice la glosa»), 475 ("Onde la glosa dice»), 507 ("la glosa dice sobre aquella palabra...» [Ro 8,35-39]), 526 («Según dice la glosa»), 536 ("como dice la glosa»), 579 ("a lo cual dice una glosa sobre el séptimo capítulo de San Mateo»).

39 Osuna 2004a, 338.

40 Osuna 2004a, 530; 1998, 367, 487, 587.

41 Osuna 2004b, 356, 406, 477, 524.

42 Osuna 2002, 1020, 1109, 1161.

43 Ibídem, 1072, 1104, 1129.

44 Ibídem, 1104.

45 Pérez García 2010, 158.

46 Ros 1936, 387, 53. Estado de la cuestión sobre Galatino en Wilkinson 2007, 58-61.

47 Osuna 1998, 486. También al comentar Da 7,9-10 en el Primer Abecedario, se apoya en «otra translación» (Osuna 2004a, 301).

48 Osuna 1998, 496. Referencias a la traducción de san Jerónimo también en Convite (Osuna 1537, ff. 71v-72r).

49 Osuna 2004a, 139. Este proceder lo mantiene durante toda su vida; así en el Convite (Osuna 1537, f. 80r), o en su Sexto Abecedario, escrito al final de sus días, siguen figurando referencias expresas a la Septuaginta (Osuna 2002, 938, 1083, 1148).

50 Por ejemplo, al referirse a Isaías 50,11, Osuna añade: «Sobre estas palabras dize san Jerónimo: ...», y añade una sentencia atribuida al mismo tomándola directamente de la correspondiente glosa ordinaria (Osuna 2004b, 255-256, nota 954). tre otros. En otro pasaje, al referirse al cese de la acción de los sentidos exteriores e interiores y de la razón durante el "arrebatamiento» en que se produce la contemplación de Dios por el alma, dice interpretar esta situación de «ceguedad corporal» y «ceguedad espiritual» "según la glosa de san Agustín sobre aquella palabra: No me verá hombre y vivirá $\left(\right.$ Ex 33,20)». ${ }^{51}$

Al proceder de esta manera, el franciscano insertaba su exposición de la Biblia en la tradición exegética y espiritual de la Iglesia, dotándola de autoridad. Y esta era una cuestión absolutamente clave para un texto como el del Tercer Abecedario que había sido puesto bajo sospecha y cuya impresión en 1527 estuvo relacionada de forma inmediata con la voluntad de Osuna de clarificar la doctrina del recogimiento a fin de deslindarla nítidamente de la del dexamiento de los alumbrados de Toledo condenados por la Inquisición en el Edicto de 1525. Referirse continuamente a lo que decían las glosas para exponer la teología mística era también un mecanismo de seguridad y respuesta frente a las críticas que habían recibido las posiciones de Osuna sobre la oración y que habían llegado a cuestionar seriamente incluso que esa doctrina del recogimiento fuese realmente la teología mística de la tradición de la Iglesia.

\section{TRADICIÓN ESPIRITUAL Y REVESTIMIENTO DE AUTORIDAD EN EL ABECEDARIO ESPIRITUAL}

Sobre el bosque bíblico, planean las autoridades de la Antigüedad y del Medievo: padres y doctores de la Iglesia, teólogos y santos, escritores eclesiásticos y también, por supuesto, los filósofos de la Antigüedad, que desfilan por las páginas de Osuna para sostener esta o aquella afirmación. Un recuento de las menciones presentes en los tres primeros Abecedarios de este conjunto de autoridades arroja resultados interesantes. ${ }^{52}$ Sobre un total de 575 menciones expresas a autores, 549 (95,5 \%) corresponden a autores cristianos (Tabla 1 ) y 26 a autores paganos, griegos o romanos (4,5\%) (Tabla 2). Entre los primeros se cuentan 36 nom-

51 Osuna 1998, 144-145. En otro lugar, comentando otro pasaje bíblico, escribe: "Assí, según que glosa sant Augustín, se puede dezir de Dios...» (Osuna 2004a, 420).

52 Hemos de avisar de que los números que se presentan a continuación deben entenderse exclusivamente como una mera contabilidad de menciones a cada uno de esos autores, solo eso. Existen citas en estos Abecedarios a diferentes autores incluidos en las listas contenidas en el Apéndice que son presentadas únicamente como debidas a "un doctor», o que sencillamente Osuna traslada a su texto sin mencionar su fuente. Al no incluir una mención expresa o explícita al nombre del autor, no las hemos contabilizado aquí, pues lo que nos interesa ahora es la apariencia del texto, no su verdadera estructura de fuentes; en cualquier caso, su número no alteraría de manera sustancial los resultados aquí presentados. Por ello hemos de insistir en que las tablas 1 y 2 recogen únicamente menciones, no citas ni siquiera fuentes empleadas, dado que, obviamente, hay autores que se traen de segunda mano, o que se vierten desde los textos de otros que se están copiando o versionando; en ocasiones, solo consiguen alcanzar el texto osuniano desde un trasvase directo a partir de las glosas bíblicas que están sirviendo para desarrollar una argumentación o guiar una interpretación. Se trata, pues, en ocasiones, de referencias de segunda mano. Así pues, el método de la mera contabilización de las menciones a autores presentes en el Abecedario nos muestra cuál es el revestimiento de autoridad con que se ha dotado al texto, una cuestión de suma importancia, y distinta, obviamente, de aquella otra relativa a qué textos sirvieron a Osuna para componer el Abecedario. 
bres (correspondientes, en realidad, a 37 autores) que trasladan la imagen de unos Abecedarios sólidamente anclados en el conjunto de la tradición eclesiástica, desde Orígenes y san Cipriano de Cartago, fallecidos a mediados del siglo III, pasando por los grandes autores y referentes de los siglos IV y V (Antonio Abad, Atanasio, Hilario, Ambrosio, Jerónimo, Agustín, Gregorio Nacianceno, Basilio y Crisóstomo) y los escritores de la tardoantigüedad entre los siglos V y VIII que tanto influyeron en la construcción de la cultura medieval y de la espiritualidad cristiana (Casiano, san Severino, Dionisio Areopagita, Boecio, Casiodoro, san Gregorio Magno, san Isidoro de Sevilla, san Juan Climaco, Isaac de Nínive y Beda el Venerable), hasta los renovadores de la teología cristiana en los siglos XI y XII (san Anselmo, san Bernardo, Hugo y Ricardo de San Víctor) y una serie de nombres que se continúan por los siglos XIII y XIV (Inocencio III, san Francisco de Asís, Alberto Magno, san Buenaventura, Escoto [† 1308], Ubertino da Casale [† 1329], Simón de Casia [† 1348], y santa Brígida [ $† 1373])$, y XV (Jean Gerson, $† 1429$, y san Bernardino de Siena, † 1444), para terminar con una mención explícita en el Tercer Abecedario al Roseto (Rosetum exercitiorum spiritualium et sacrarum meditationum) del autor flamenco Jan Mombaer, fallecido ya en 1501 y cuyo nombre no se menciona, y que es el escritor más reciente cuyo uso es reconocido por Osuna de manera explícita en el Abecedario. ${ }^{53}$

Esta lista no es resultado del azar, en absoluto. Refleja el preciso conocimiento que tenía Osuna de la historia del desarrollo de la teología cristiana, revela un aprendizaje sistemático de la misma a partir de sus fuentes principales y muestra que su tarea de escritura se fundaba radicalmente sobre los principios de la tradición y la autoridad, transmitidos a través de la sucesión secular de las generaciones, algo que además se quería demostrar con claridad meridiana ante todo potencial lector o censor. Ello se pone de manifiesto cuando se comprueba que, entre todos ellos, sobresalen los cuatro autores que en 1295 habían recibido del papa Bonifacio VIII el título honorífico de "doctor de la Iglesia», a saber, Ambrosio, Jerónimo, Agustín y san Gregorio: ${ }^{54}$ acumulan respectivamente $13,37,112$ y 84 menciones, es decir, 246 de 575, el 42,8\% del total. No obstante, es necesario apuntar que, aunque la identificación de este san Gregorio con san Gregorio Magno es la más obvia y sin duda acertada en muchas ocasiones, como ya señalara el propio Ros, ${ }^{55}$ en ocasiones las citas proceden de escritos de san Gregorio de Nisa, otra figura fundamental en la historia de la mística cristiana y cuyos textos habían sido familiares a los franciscanos desde la baja Edad Media; ${ }^{56}$ en este punto, se hace necesario un estudio crítico de esas citas que sobrepasa las posibilidades de estas páginas, siendo de sumo interés pues señala una conexión con la mística cristiana oriental que habitualmente ha sido olvidada en los estudios de la mística

53 Aunque no lo cite expresamente, Osuna ha recurrido a Mombaer también en el Primer y Segundo Abecedario, y tres libros del Rosetum (Schala communionis, Ruminatorium nominum y Dominicarium) se cuentan entre las fuentes principales del Gracioso convite de nuestro franciscano (Ros 1936, 204-219, 284-287, 316-317).

54 Drobner 2001, 21. De hecho, el mismo Osuna cuenta a san Cipriano, san Ambrosio, san Jerónimo y san Agustín entre «los más altos doctores de la Yglesia» (Osuna 1550, f. 7v).

55 Ros 1936, 53, 55, 284, 362.

56 Vid infra. española, aun cuando es posible que Osuna confundiera la autoría de los textos de ambos Gregorios.

Junto a los anteriores, no faltan los cuatro teólogos que más tarde, en 1568, serían elevados por Pío $V$ también al rango de doctores de la iglesia como padres de la iglesia de oriente, a saber, Atanasio, Basilio, Gregorio Nacianceno y Juan Crisóstomo, ${ }^{57}$ cuya presencia contribuye de manera no menor a revestir de autoridad, por su antigüedad y prestigio, el texto de los Abecedarios, y ello a pesar de su presencia secundaria en el mismo (solo 21 menciones, el 3,6 \%). ${ }^{58}$ Dado el carácter de esta obra relativa a la teología mística, el Libro llamado Abecedario espiritual cita de manera enorme a san Bernardo (93 menciones, 16,1\%) y trae con relativa frecuencia a Hugo y a Ricardo de San Víctor (26 menciones, el 4,5\%), sus renovadores en el siglo XII y proyectores de la misma hacia el futuro, sobre el fondo ineludible del pseudo Diniosio Areopagita. La huella franciscana está presente, como no podía ser de otra manera, gracias a menciones directas al propio san Francisco de Asís, san Buenaventura, Escoto, Ubertino y san Bernardino de Siena, cuyo prudente número (24, el 4,1 \%) no explicita, quizás deliberadamente, el peso real del franciscanismo en el texto. ${ }^{59}$ Por último, destaca la figura de Jean Gerson, canciller de París, sobre el que luego volveré, y que acumula 70 menciones (12,1\%), 52 de ellas en el Tercer Abecedario.

Por otra parte, si consideramos solo a aquellos autores que por su número de menciones resultan habituales en las páginas de Osuna, la lista se reduce drásticamente: san Agustín (112), san Bernardo (93), san Gregorio (Magno y de Nisa, los dos) (84) y Gerson (70); los cinco acumulan 359 menciones, el $62,5 \%$ de todas ellas. A una enorme distancia se encuentran ya Jerónimo (37), Ricardo de San Víctor (22), san Cipriano (22), Crisóstomo (17), Buenaventura (14), Ambrosio (13) y el Areopagita (12), siete autores que suponen otras 137 menciones, el 23,8\%; de los restantes 24 autores ninguno alcanza la decena de menciones expresas, sumando en total 78 , el $13,5 \%$. Estos datos señalan, finalmente, cuáles eran los pilares de la autoridad en la arquitectura del Libro Ilamado Abecedario Espiritual, perfectamente identificables en la tradición espiritual a través de la terna Agustín, Gregorio y Bernardo (quien, no lo olvidemos, aunque fallecido en 1153 era percibido como el último de los padres), ${ }^{60}$ a la que se ha añadido un autor relativamente reciente para entonces como era Jean Gerson, lo cual requiere de una explicación. Especialmente estos cuatro, asociados aquí o allá con algunos de los restantes, servirán repetidamente para

57 Drobner 2001, 21.

58 Aunque carecemos todavía de un estudio crítico que nos permita dilucidar en qué medida muchas de estas citas eran de primera mano o no, no debemos olvidar el notable acceso a la literatura monástica griega (Juan Climaco, Isaac de Nínive, Crisóstomo, Basilio, Atanasio, Gregorio de Nisa, etc.) que tuvieron los franciscanos, no solo debido a su presencia en Oriente, sino por la vía de la experiencia de Angelo Clareno (traductor de la Scala Paradisi de Climaco) y de otros espirituales franciscanos en Grecia y Armenia a finales del siglo XIII y principios del siglo XIV, lo que hizo posible el conocimiento de un buen número de esos textos entre los franciscanos de Italia y de la península ibérica durante los siglos XIV y XV (Gribomont 1960; Musto 1983; Pérez García 2014, 81-87; Nardelli 2017, XXXIII-XLVI).

59 Vid Narbona 1910.

60 Drobner 2001, 21. 
formar cadenas de autoridades que apuntalen la posición de Osuna en muchos de los temas que expone. ${ }^{61}$

En ese aparente caos de menciones resulta posible identificar a los que, sin duda, constituyen los pilares de la arquitectura textual de Osuna en el Libro llamado Abecedario Espiritual, especialmente san Bernardo y Ricardo de San Víctor. Ros, tras identificar 25 de las menciones a san Bernardo, quedaba con "l'impression qu'Osuna avait longuement feuilleté les livres de saint Bernard et de ses disciples». En efecto, Osuna conocía perfectamente tanto las obras auténticas de san Bernardo (Epistolae, Sermones in Cantica Canticorum, Sermones varii) como una larga serie de textos medievales apócrifos atribuidos al mismo que jugaron un papel fundamental en la espiritualidad medieval, tales como la Epistola seu tractatus ad fratres de monte Dei, la Scala claustralium del cartujo Guigues II, las Meditationes de cognitione humanae conditionis, el Tractatus de interiori domo, la Formula honestae vitae, el Tractatus de conscientia y Octo puncta perfectionis assequendae, vinculados a la tradición monástica. ${ }^{62} \mathrm{~A}$ la tradición cisterciense pertenecen asimismo algunas de las citas que Osuna atribuía erróneamente a san Cipriano, que corresponden en realidad al cisterciense Arnaud, abad de Bonneval, amigo del propio san Bernardo y fallecido en $1156 .{ }^{63}$ Junto a todos estos, Ricardo de San Víctor juega también un papel principal en el Tercer Abecedario a través de su Benjamin minor, Benjamin major y el Tractatus de gradibus charitatis, ${ }^{64}$ y en el Cuarto Abecedario, donde Osuna utilizó también Explicatio in Cantica Canticorum, De missione Spiritus Sancti sermo y el Tractatus de quatuor gradibus violentae charitatis. ${ }^{65}$ De todo ello se concluye que Francisco de Osuna al redactar en la década de 1520 el Libro llamado Abecedario espiritual utilizó exactamente los mismos textos de espiritualidad que habían guiado al reformismo franciscano desde comienzos del siglo $\mathrm{XV}$ y que sirvieron en la generación anterior para redactar las primeras síntesis sistemáticas de espiritualidad en lengua castellana, a saber, el Carro de dos vidas de Gómez García, y el Exercitatorio de la vida espiritual del benedictino García Jiménez de Cisneros, ambos publicados en $1500 .{ }^{66}$

\section{JeAn GERSON EN EL TERCER ABECEDARIO ESPIRITUAL}

Ya Pierre Groult, al preguntarse sobre la huella de la literatura mística de los Países Bajos en el Tercer Abecedario de Osuna, se dio cuenta de que Osuna contaba «entre sus maestros más venerados al canciller Gerson», y ello por considerarlo dotado "de autoridad incontestable, quizá igual a la de san Agustín, san Bernardo y san Buenaventura». ${ }^{67}$ Groult identificó en el Tercer Abecedario el uso directo por Osuna de un buen número de los tratados de Gerson, a saber: Theologia mystica, De monte contemplationis, De simplificatione cordis, De religionis perfectione, Tractatus de signis bonis et malis, De consolatione theologiae, Contra foedam tentationem blasphemiae, Questiones cum res-

\footnotetext{
61 Osuna 1998, 347-349, 503-504, 508-512.

Ros 1936, 354-357.

Ibídem, 362.

Ibídem, 357-358.

Ibídem, 373-375.

Pérez García 2014.

Groult 1976, 152-153.
}

ponsibus, De distinctione verarum visionum a falsis. ${ }^{68}$ Por su parte, Fidèle de Ros concluyó que en el Tercer Abecedario se habían utilizado al menos quince tratados de Gerson; el conocimiento que tenía Osuna del canciller de París se confirma al consultar otras de sus obras: así, en Ley de amor o Cuarto Abecedario Espiritual se citan el Centilogium y el Sympsalma super Cantica Canticorum; en el Gracioso Convite Osuna recurre a cuatro obras eucarísticas de Gerson; y en el Norte de los estados también es perceptible la huella del canciller de la universidad de París. ${ }^{69}$ El mismo Osuna, aparte de las numerosas referencias a Gerson, menciona explícitamente algunos de sus libros, asi «un libro que se llama Monte de contemplación» escrito en francés, ${ }^{70}$ y el Tratado de la temerosa consciencia ${ }^{71}$ no vacilando en afirmar que determinados pasajes que incluye en sus escritos estaban tomados directamente de alguno de sus libros. ${ }^{72}$

Los calificativos que Osuna emplea para referirse a Gerson no dejan lugar a dudas sobre el prestigio que este disfrutaba en Castilla a comienzos del siglo XVI: «el doctor Juan Gerson» ${ }^{73}$ "el Gran Chanciller de París», ${ }^{74}$ "el venerable Gerson» ${ }^{75}$ "el cristianísimo Gerson», ${ }^{76}$ "christianíssimo y sapientíssimo Gerson», ${ }^{77}$ y "el cristianísmo Gerson, no menos santo que letrado", ${ }^{78}$ calificación esta última de gran interés pues al asociar a la persona de Gerson tanto la virtud como las letras, se pretendía dar a entender que su opinión en lo referente a materias espirituales estaría dotada de un valor singular, puesto que aunaría tanto el saber propio del conocimiento racional de los letrados como la sabiduría derivada del amor y la santidad, característica de la vida espiritual; se trataba de una apreciación sumamente valiosa, dadas las quejas de Osuna y otros muchos escritores espirituales contra los letrados incapaces de valorar las cuestiones relativas a la teología mística por su ignorancia del conocimiento por amor. A ellos se dirige de manera concreta para reprocharles su incapacidad para entender a Dionisio Areopagita, puntal de la teología mística por antonomasia, y recordar que Gerson había sido uno de sus máximos intérpretes, como de hecho lo fue: ${ }^{79}$ "Si tú no entiendes a san Dionisio, no por eso está por entender, ca Gerson está ahí y otros doctores santos que lo entendieron y pusieron avisos y cautelas contra las asechanzas del demonio, que en las cosas más altas se trabaja más de nos engañar».$^{80}$

La autoridad de Gerson explica que Osuna recurra a él de manera tan frecuente, precisamente para apuntalar sus posiciones en toda una serie de debatidas y delicadas cuestiones relativas a la teología espiritual:

- Frente a los que "dudan», Osuna afirma la certeza de que el ejercicio del recogimiento no es sino la teología mística enseñada por el apóstol Pablo a

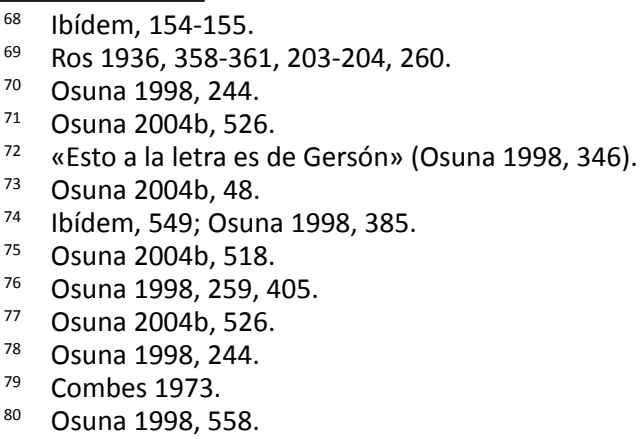


Dionisio Areopagita ${ }^{81}$ y transmitida después por «los doctores auténticos que hablaron en esta materia», desde san Antonio Abad, "el santo abad Isaac», San Cipriano, san Agustín, san Gregorio, Hugo de San Víctor, san Bernardo, san Buenaventura, Gregorio Nacianceno y por supuesto, Gerson, principal autoridad alegada en la exposición de la defensa de la veracidad de la teología mística contenida en los capítulos 6 y 7 del tratado 21 del Tercer Abecedario; ${ }^{82}$ tras aducirlos a todos ellos, todavía apuntará: "De innumerables testimonios muy creíbles que ha de santos y aprobados doctores en favor de la presente letra, no he querido traer sino los menos; y creo que bastan para los no ejercitados». ${ }^{83}$

- La excelencia de la teología mística sobre la especulativa ${ }^{84}$ debido a la superioridad del conocimiento adquirido por amor sobre cualquier otra clase de aprendizaje; ${ }^{85}$

- El destino universal de la teología mística, que debe ofrecerse y enseñarse en lengua vulgar también a los seglares, y no solo a los religiosos; ${ }^{86}$

- La necesidad de acudir a un "maestro» para ser guiado en la práctica de los ejercicios espirituales ${ }^{87}$ y de que dicho maestro tenga "experiencia de la vida espiritual que ha de enseñar»; 8

- Y sobre todo, las delicadísimas cuestiones relativas a los dones místicos, los gustos y tentaciones espirituales y el peligro del engaño diabólico que sobrevolaba la práctica de la oración contemplativa, todas ellas largamente debatidas y hacia las que Osuna sostenía una posición extremadamente positiva.

Respecto a los dones especiales recibidos de Dios por aquellos que practican la oración de recogimiento, Osuna entiende que la humildad es suficiente garantía para no ser engañado por el demonio, ${ }^{89}$ y que, dado que el recogimiento debe enseñarse a todos, también los dones místicos recibidos en el mismo deben darse a conocer públicamente

81 Pérez García 2019.

82 Osuna 1998, 561-569.

83 Ibídem, 567.

84 Ibídem, 200.

85 «No hay vista más penetradora, según dice Gersón, que la del amor, ni más aguda para llegar hasta lo íntimo del corazón, con lo cual el esposo y la esposa se desean ver el uno al otro, como parece en los Cánticos (Cant 3,4)» (Ibídem, 422).

86 Ibídem, 244-245.

87 Ibídem, 270. Se trata de una cuestión que preocupaba profundamente a Osuna, y que brota en diferentes pasajes de sus textos, por ejemplo en relación a los escrupulosos de conciencia: «El que es muy escrupuloso busque buen maestro a quien crea teniendo suspecha del propio parecer», maestros que vayan delante (que sean "delanteros», dice nuestro franciscano) en el camino del espíritu, de modo que quienes son "nuevos en el espíritu» y «no pueden de ligero entender las cosas espirituales», no se ahoguen entre los escrúpulos y las dudas que surgen en la práctica de los ejercicios espirituales y que les son infundidos por malos maestros carentes de experiencia espiritual, muchas veces los propios prelados de la orden a quienes Osuna califica con dureza de "hipócritas y fieras singulares que pacen la viña del Señor»; la escasez o falta de verdaderos maestros espirituales es un mal que Osuna no deja de señalar (Osuna 2004b, 525-528).

88 Osuna 1998, 269-270.

89 «... así que, si tienes humildad, hallarás la tierra segura, conforme a lo cual dice Gersón: todas las amonestaciones interiores, todos los instintos vehementes, toda revelación, todo milagro, todo amor extático, toda contemplación, todo arrobamiento y, finalmente, toda nuestra interior o exterior operación, si humildad precede y acompaña y se sigue, si ninguna cosa se mezcla que la destruya, créeme que todas las cosas dichas tienen señal que son de Dios, o de su buen ángel, $\mathrm{ni}$ eres engañado» (Ibídem, 504). por aquellos que los experimentan, ${ }^{90}$ especialmente por los religiosos que los reciben, que deben comunicarlos a sus prelados para que su orden religiosa pueda difundirlos por doquier. ${ }^{91}$

En relación con el gusto espiritual, Osuna también recurre con frecuencia a Gerson. Así, afirma conocer quince razones de Gerson acerca del «porqué el Señor aparta de nos el gusto de la devoción $"{ }^{92}$ y trae a Gerson para posicionarse a favor de que los devotos no deben dejar de querer unirse a Dios aunque sus intenciones no sean totalmente limpias «sino que lo quieran gustar por su propio interés, no por eso deben dejar el tal gusto ${ }^{93}$ Finalmente, polemiza duramente contra los letrados «indevotos» que criticaban los gustos espirituales "con algunos espantos demasiados», asustando a los devotos con la idea de que las consolaciones recibidas en el recogimiento eran causadas, en realidad, no por Dios, sino por su amor propio, o incluso fingidas por el mismo demonio, ${ }^{94}$ quien, según una larga tradición teológi-

90 En esta cuestión, Osuna arrastra la autoridad de Gersón desde la defensa de este acerca de la divulgación general de la teología mística a la posición favorable a la publicitación de los dones místicos extraordinarios: «... hay empero, algunos que dicen no ser bien manifestar el hombre el don que ha recibido [...] Los primeros decían que no se debería esto manifestar a seglares; estos dicen que si alguno ha recibido del Señor gracia acerca del recogimiento, que la esconda y calle, y que si alguno quisiere saber algo que busque libros o suplique al Señor, que da a todos en abundancia; mas que él no le dirá palabra ni descubrirá el secreto que Dios le ha manifestado, ni quiere industriar a nadie en este ejercicio, pues que hay otros que bastan. Este postrer yerro es peor que el primero, pues tiene menos con que defenderse; $y$ por no haber visto menos personas engañadas en este que en el otro, quiero poner aquí algunas razones en contrario» (Osuna 1998, 245). En otro pasaje llega a afirmar que la convicción que a veces se forman los espirituales en su interior de «que será mejor callar las tales revelaciones» dado que "no será creído si lo dice», procede precisamente de un engaño inspirado por el propio demonio (ibídem, 561-562), con lo que el franciscano cambia radicalmente la dirección en la que se produciría el engaño diabólico.

91 «A esto dice el cristianísimo Gersón que es obligado el religioso a responder enteramente a su prelado cuando le pregunta de las cosas interiores que Dios le ha comunicado, y a declararle por extenso, según su voluntad, lo que acerca de esto le pregunta, para que el prelado disponga de aquellos bienes de la orden según viere convenir a su república y común utilidad de sus frailes; y yo creo que el prelado, pues en lo espiritual ha de ser solícito, es obligado a saber e inquirir esto, para que la orden se sirva y aproveche de aquellos bienes [...] así los religiosos que reciben de Dios algunos especiales dones no los deben esconder ni pensar que son suyos propios, sino de la orden a la cual deben servir con ellos» (Osuna 1998, 259-260). Esta idea, siguiendo de nuevo a Gerson, también en Segundo Abecedario, Osuna 2004b, 48: «... devrías notificar a tu perlado en confessión lo que sientes orando [...]. Y tú, si verdaderamente sientes a Dios, eres obligado a se lo notificar en el caso ya dicho y después dexarte totalmente a su disposición».

92 Osuna 1998, 349.

93 Ibídem, 346.

94 «Es de tanta excelencia el gusto espiritual, que pienso ser casi imposible que no lo alabe el que lo ha tenido [...] No he querido hacer distinciones de gustos, pues los que los reprueban tampoco los quieren distinguir, y porque en otra parte hallarás esta distinción [...] Algunos libros he leído que ponen menos bien esto de la consolación espiritual con algunos espantos demasiados y que no tienen mucha verdad, reprehendiendo los sentimientos de la devoción que alabaron los santos; y esto pienso que vino de no haber gustado cuán suave es el Señor, porque estos sentimientos, como dice Gersón, no se dejan entender sino de los que los sienten...» (Ibídem, 351). Y continúa: «Dicen los indevotos que hacen los recogidos más caso que deberían de las consolaciones que sienten; mas no prueban esto, sino levántanlo en su cabeza, [...] según dice Gersón, gran señal es del amor de Dios sentir consolación, y mayor que no el ayuno, aunque sea bueno...» (Ibídem, 
ca que interpretaba 2 Corintios 11,14 , se transfiguraba en ángel de luz para engañar a los hombres y mujeres en los caminos del espíritu. ${ }^{95}$

Finalmente, Osuna también rechaza las críticas de quienes atemorizan a los devotos con las terribles tentaciones que se padecerían en el recogimiento, para lo cual recurre repetidamente a Gerson: ${ }^{96}$

Según dice Gersón, este ejercicio es más invencible que otro ninguno, aunque es más impugnado [...] La tentación que es común a todo ejercicio, mal parece aplicarla solamente a uno por lo infamar, ca, según dice Gersón, y también la experiencia da de ello testimonio, muchas veces sobrevienen torpes pensamientos a los que piensan en la sacra pasión. ${ }^{97}$

En definitiva, Gerson es utilizado por Francisco de Osuna para garantizar que el ejercicio del recogimiento no es otro que la tradicional teología mística, y que esta, que debe sacarse fuera de los muros del claustro donde se había desarrollado durante la Edad Media, era una vía segura, ${ }^{98}$ y por ello se podía ofrecer a todos, atenuando para ello la gravedad de los serios recelos acerca de los peligros, tentaciones y engaños avisados por numerosos teólogos medievales.

Junto a estas cuestiones graves, Osuna aprovecha también multitud de consejos de Gerson sobre la vida espiritual: en favor de la necesidad del silencio interior ${ }^{99} \mathrm{y}$ de la perseverancia en la práctica del recogimiento aun careciendo de devoción; ${ }^{100}$ sobre la posibilidad de orar siempre; ${ }^{101}$ acerca de la importancia de la humildad en el recogimiento, ${ }^{102}$ los daños causados por el "ayuno indiscreto» al recogimiento ${ }^{103}$ o la obligatoriedad de la clausura para el religioso; ${ }^{104}$ o en relación con la guarda del propio corazón para evitar la dispersión de los sentimientos y de los pensamientos, criticando el exceso de celo de los principiantes contra los pecados ajenos $^{105}$ y la murmuración, ${ }^{106}$ previniendo acerca de la corrección fraterna, ${ }^{107}$ y avisando de que el devoto debe ocu-

352). Finalmente, rechaza el peligro del engaño propio o diabólico para quienes practican los mandamientos y viven con humildad: «Si gustas en Dios, en tu ánima tienes la mayor señal que pueda ser del supremo amor de Dios, y por eso no te espante nadie diciéndote que es amor propio, y aunque te digan que allí se puede esconder el demonio, diles tú que también se puede esconder tras la puerta de la iglesia, mas por eso tú no has de dejar entrar allá; ca signándote puedes ir seguro, y con la debida examinación que hagas en esto puedes también estar seguro; ca, según se dice, a los limpios todas las cosas son limpias; de manera que, aunque viniese el demonio a fingir en tí todas las consolaciones que pudiese, no te ensoberbeciendo tú, ni te apartando de los mandamientos de Dios, él hace de su daño y tú siempre sales con ganancia» (Ibídem, 352).

95 Crouzel 2015, 181 y 190. Andrés Martín 1994, 141-145.

96 Osuna 1998, 528, 541-542.

97 Ibídem, 522-523.

98 «Según el mismo Gersón dice, y según lo he platicado con personas en este negocio muy ejercitadas, que esta vía es segura y tiene menos en que trompicar que otras» (ibídem 1998, 183).

99 Ibídem 1998, 148.

100 Ibídem 1998, 592. También en Segundo Abecedario, Osuna 2004b, 528.
101 Osuna 1998, 385.
102 Ibídem, 511.
103 Ibídem, 405.
104 Ibídem, 286.
105 Ibídem, 572
106 Ibídem, 575, 578.
107 Ibídem, 579-580.

parse de cultivar su propia virtud y no distraerse prestando atención a los defectos ajenos. ${ }^{108}$

\section{EL TERCER ABECEDARIO ESPIRITUAL EN EL LABERINTO DE LOS ALUMBRAdos de TOLEdo: OSUNA FRENTE A PEDRO RUIZ DE ALCARAZ EN ESCALONA}

Es conocido el hecho de que Francisco de Osuna abrió su Tercera parte del libro llamado Abecedario espiritual con una dedicatoria dirigida a don Diego López Pacheco, duque de Escalona y marqués de Villena. En ella, Osuna daba a entender con claridad que el marqués y otras muchas personas habían conocido y estimado el libro en una versión manuscrita anterior, ${ }^{109}$ y que era ahora cuando estaba al fin terminado. ${ }^{110}$ Ello se explica porque Osuna hubo de visitar Escalona, donde residía el marqués, en algún momento del periodo 1522-1524. Se trataba de una localidad convertida en un activo centro de espiritualidad en torno al convento franciscano de la villa, especialmente desde que en 1522 este se había convertido en una de las casas de recolección que daban cobijo a las tendencias descalzas que proliferaban en la orden franciscana. ${ }^{111}$ Allí, tanto el propio Osuna en persona como alguna versión manuscrita sin terminar del $\mathrm{Li}$ bro llamado Abecedario espiritual entraron en contacto con diversos espirituales, entre los cuales se contaba Pedro Ruiz de Alcaraz, más tarde condenado como uno de los líderes del grupo de los llamados alumbrados de Toledo.

En efecto, durante los primeros meses de 1523, Alcaraz, vecino de Guadalajara, donde había vivido durante años trabajando para los condes de Pliego, pasó al servicio, como contador, de don Diego López Pacheco. Alcaraz era un hombre casado, descendiente de una familia de escribanos judeoconversos y fue recomendado al marqués por Antonio de Baeza, un hombre rico ${ }^{112}$ que era vecino de Valladolid, ${ }^{113}$ además de regidor de la ciudad de Toledo (desde 1517) (114 $^{14}$ y alcaide del alcázar de Escalona. Alcaraz vivió en Escalona aproximadamente un año, hasta la primavera de 1524, aunque no de forma continuada, pues en ese tiempo volvió a Guadalajara para ver a su familia, pasó por Alcalá de Henares y Toledo, y viajó a Valladolid, todo ello antes de ser detenido por la Inquisición en Toledo a finales de abril de $1524 ;{ }^{115}$ durante ese tiempo, Alcaraz se introdujo en la clientela de su nuevo señor, explicando sus propuestas religiosas

108 Ibídem, 581-583.

109 «Muchas personas de estima han amado el presente libro; empero, porque siento que el amor que Vuestra Señoría le tiene excede al de todos, y aun al mío, se lo presento», y antes se refiere a «el gran amor que le tiene» el marqués a este libro (ibídem, 85-86).

110 La importancia que daba Osuna al hecho de que esta versión impresa era la verdadera y terminada según su voluntad queda de manifiesto en el comienzo de la dedicatoria del Tercer Abecedario, que trata precisamente de que en el «cumplido fin de la buena obra que comienza consiste su virtuoso y alegre descanso" (ibídem, 85).

111 Salazar 1612, 82; Meseguer 1961, 20; Lejarza 1962, 76; Pérez García 2005a, 190.

112 Véase su inventario de bienes post mortem de 1530 (AHNo: Baena, C. 261, D. 37-39).

113 AHNo: Baena, C. 351, D. 3-5. Partición de bienes de Pedro de Baeza. Valladolid, 8-II-1523. Por su casa de Valladolid también pasó Alcaraz, como se afirma en el proceso inquisitorial de este.

114 AHNo: Baena, C. 261, D. 45.

115 Pérez García 2005a, 203-204. 
sin ningún tapujo ante él y su familia, en su casa y en su villa. ${ }^{116}$

En Escalona, Alcaraz entró inmediatamente en contacto con el clima de revelaciones y profecías promovidas por los frailes franciscanos del convento de la villa. Muy pronto, Alcaraz se enfrentó a los frailes. ${ }^{117}$ Tanto es así, que varios meses después de su detención por la Inquisición, seguía pensando, equivocadamente, que las denuncias que habían propiciado su prendimiento habían partido de los franciscanos de Escalona. Por ello, en un escrito ${ }^{118}$ presentado desde su prisión inquisitorial de Toledo y fechado a 29 de octubre de 1524, explicaba a los inquisidores los sucesos de que había sido testigo en Escalona desde febrero de 1524 hasta la Semana Santa de aquel mismo año. Según Alcaraz, fray Francisco de Ocaña, predicador del convento de Escalona, anunciaba en sus sermones el fin de los tiempos y la reforma de la Iglesia con frases atrevidas como la que afirmaba que «los que la tenían agora habían de ser echados como puercos della»; además, Ocaña afirmaba que aquel mismo año el rey Francisco I sería desposeído de su reino (no olvidemos la situación de guerra abierta con Carlos V), y que él, junto con el guardián del convento de Escalona, fray Juan de Olmillos, habrían de ir a Roma para proceder a la reforma de la Iglesia, y allí «este buen viejo del marqués

116 Ibídem, 191-195.

117 Ibídem, 195-198. El primero en referirse a este conflicto en Escalona fue Serrano y Sanz 1903, y luego lo hicieron Bataillon y otros. Más tarde volvió sobre el asunto Nieto (1977a, traducido al español en $1979,585-602)$, quien, aunque pretende haberse apoyado en la lectura directa del proceso inquisitorial contra Alcaraz, no hace sino seguir las informaciones ofrecidas en su día por Serrano y Sanz; la falta de conocimiento de las fuentes primarias no es una causa secundaria para el desaguisado interpretativo que presenta, plagado además de errores de bulto en el nivel de la información y los hechos. Márquez (1971) demostró y Ortega Costa $(1978,12-13)$ corroboró que Nieto no consultó el proceso de Alcaraz para la primera edición (1970) de su libro sobre Juan de Valdés; después tampoco lo hizo. La falta de conocimiento que tiene Nieto acerca de cómo los términos «alumbrado», "dejado» y «recogido» aparecen en el proceso de Alcaraz o en los textos de Osuna, le lleva a aplicar el de "alumbrado" a individuos que nunca fueron calificados como tales, y a confundir los términos, mezclando los usos históricos dados a los mismos en las fuentes con aquellos otros que él crea arbitrariamente (como el de «alumbrados apocalípticos» que aplica a Olmillos, quien era, precisamente, enemigo mortal de Alcaraz, cf. la propia declaración de Olmillos contra Alcaraz ante la Inquisición, AHN: I, leg. 106, n. 5, f. 74r). A Osuna dedica algunas páginas (Nieto 1979, 139-151) que, de nuevo, mezclan caprichosamente los términos históricos: «El primer libro de Osuna, titulado Tercer abecedario espiritual, está muy directamente relacionado con el presente estudio sobre Valdés por ser el producto más acabado y perfecto de ese otro movimiento de los alumbrados franciscanos llamado de los recogidos [...] El Abecedario es de inestimable valor por cuanto nos permite observar otra variante del movimiento de los alumbrados; la encabezada por frailes franciscanos cuyos miembros era conocidos con el nombre de recogidos ...». Solo el limitado conocimiento que Bataillon tenía de las fuentes relativas a los alumbrados y de la obra de Osuna puede explicar el impulso que el hispanista francés dio al libro de Nieto, como este reconoció en el prefacio a su edición española (Nieto 1979, 17). Las confusiones de Nieto se han transmitido a una parte de la historiografía. Su desconocimiento es vertido de nuevo en la reseña que dedicó (Nieto 1977b) a Los recogidos de Andrés Martín (1975), sin percatarse de que la delimitación de la ortodoxia de los recogidos y la heterodoxia de los alumbrados que hace Andrés deriva de las decisiones del Santo Oficio contenidas en el proceso contra Alcaraz, cuando, actuando como tribunal de la fe católica, dictaminó sobre las mismas.

118 AHN: I, leg. 106, n. 5. Proceso de Alcaraz, ff. 7r-11v. De este documento proceden las citas siguientes a menos que se indique algo distinto. ha de poner en su silla al papa». Cuando Alcaraz preguntó a Ocaña que cómo sabía que aquello era verdad, el fraile le respondió que le había sido revelado por el mismísimo Dios a Olmillos durante sus arrobamientos; además, Ocaña no vaciló en explicarle que esperaban que pronto Olmillos recibiría la impresión de las llagas de san Francisco. En su alegato ante el Santo Oficio, Alcaraz repitió insistentemente que, en su opinión, aquellos frailes habían perdido el juicio (como comentó también al propio Antonio de Baeza, testigo asimismo de las predicaciones) y que eran víctimas de un engaño diabólico; "es ilusión y engaño del demonio», llegó a decir a Ocaña, era un «engaño suyo en que él estaba interiormente».

Con la intención de poner fin a tales excesos, y en un contexto de pugna por ganar la confianza del marqués en cuestiones religiosas, Alcaraz marchó a Toledo a denunciar los hechos ante las autoridades franciscanas de la provincia de Castilla. Aquí, en el gran convento de San Juan de los Reyes, se entrevistó con el vicario de la casa, fray Pedro Ortiz, y le informó «del engaño de los frailes», y después trató de lo mismo con el guardián del convento, fray Barnabás (Bernabé de Ávila), y con el provincial, fray Andrés de Écija. Estos le dijeron que se encargarían del asunto y, para evitar el escándalo, le rogaron no le diese más publicidad: «no hables en lo de nuestros frailes, pues nadie no tiene jurisdicción sobre ellos sino sus prelados», le habrían dicho; por su parte, fray Andrés le prometió que iría a Escalona para "remediar» todo. Era el tiempo de la Cuaresma de 1524. El provincial, efectivamente, acudió a Escalona y allí dijo la misa el día del Jueves Santo en la iglesia del convento, en un altar que Olmillos había situado en mitad de la misma («para que más públicamente se viese su misa y sus milagros», explicaría Alcaraz); cuando Olmillos comulgó, entró en éxtasis:

Comulgó el de Olmillos y luego tuvo sus trasponimientos y comenzó con ellos a hablar como solía. Y el provincial mandó que cesase el canto de los frailes, que cantaban la Pange Lingua, para que se oyese lo que decía el de Olmillos, y el provincial cubierto de lágrimas de lo ver traspuesto e oír lo que así decía, estuvieron hasta que acabó su sermón.

Para Alcaraz, aquel momento supuso una dura derrota ante las autoridades de la provincia: «Yo estaba que parecía que el corazón me comían perros», dirá más tarde. Un apunte de Alcaraz nos informa de que no todos los frailes estaban conformes con aquellos («algunos frailes de los de la casa [...] no estaban bien en aquellos malos milagros»), entre ellos el anterior guardián de Escalona, un tal Lillo. Ante lo sucedido, fray Andrés de Écija se limitó a ordenar que Olmillos dijese su misa en el claustro del convento, y no en la iglesia (aunque, según Alcaraz, se permitía allí el acceso a quien quisiera acudir), y que Ocaña predicase exclusivamente al marqués, pero no de forma pública. Era una forma de restringir la publicidad de tales fenómenos, pero nada más.

Hasta aquí la historia que nos interesa recordar ahora. En este relato, que solo podemos conocer por la versión ofrecida por el propio Alcaraz a los inquisidores con el fin de intentar salir de la prisión en la que había sido encerrado, encontramos toda una serie de puntos de engarce con el proceso de redacción del Tercer Abecedario. Desde luego, pensamos que no son ajenas a estas circunstancias las quejas del propio Osuna contra los prelados que limitaban la pu- 
blicidad de los dones extraordinarios recibidos en la oración y contra los frailes recelosos de tales fenómenos. ${ }^{119}$ Pero es en el problema del engaño diabólico donde nos queremos centrar ahora. En efecto, en su alegato contra los supuestos engaños diabólicos sufridos por los frailes de Escalona, Alcaraz no dudó en recurrir a la autoridad del Libro de la vida de Ángela de Foligno («según he leído en el libro de santa Ángela de la manera que el demonio suele engañar a personas espirituales»); como se sabe, es un tema que efectivamente aparece en este libro de revelaciones. ${ }^{120}$ En otra confesión presentada más tarde, Alcaraz narra cómo recurrió también a una traducción de un escrito de Gerson para probar ante el marqués el engaño que padecían los franciscanos de Escalona:

Sintiendo el daño conocido de estas tales personas y que con ello y con sus vanidades envanecían y engañaban a otros también, y acuérdaseme que hice que el marqués viese unos dichos del Gersón que Antonio de Baeza trasladó del de latín en romance, que todos hablaban en estos avisos de los engaños del demonio, semejantes a los que yo allí veía, y así a otros los mostré por lo mismo.

Sus trabajos fueron, desde luego, infructuosos, pues su detención en abril de 1524 puso fin a esta lucha, y el triunfo de los franciscanos en Escalona fue absoluto, como se concluye del hecho de que a partir de 1525 la provincia de Castilla quedase bajo el patrocinio directo de los duques de Escalona, en cuya villa celebrarían en adelante sus capítulos provinciales. ${ }^{121}$ En cualquier caso, lo que queda claro es que Gerson era considerado como una autoridad en la materia del engaño diabólico, un problema que no era nuevo en la provincia franciscana de Castilla. ${ }^{122}$ Francisco de Osuna, al recurrir a él para apuntalar el Tercer Abecedario, escogía, sin duda, la autoridad necesaria en tal punto, destruyendo, de paso, las difundidas objeciones de Alcaraz en el entorno de Escalona.

Otros testimonios recogidos en su proceso inquisitorial apuntan a que Gerson estuvo en el centro de un intenso debate habido entre los dexados o alumbrados y los recogidos. En la sentencia de 1529 constaba la acusación contra Alcaraz de haber dicho que «el súbdito debajo del prelado no tenía que dar cuenta a Dios ni a nadie de su ánima», ${ }^{123}$ una opinión radicalmente contraria a la expresada por Osuna; otra acusación reflejaba el enfrentamiento con el recogimiento: «que el que estaba en este dexamiento, que no había menester oración, ni recogimiento, ni lugar determinado». ${ }^{124}$ Tal acusación probablemente partía de la siguiente afirmación de Alcaraz: "que dize el Jersón el que sabe andar de dentro y pensar poco las cosas de fuera no busca lugares ni espera tiempos para aver devotos exercicios». ${ }^{125}$ Otra posición que fue radicalmente combatida en el Tercer Abecedario. ${ }^{126}$

119 Osuna 1998, 245-249, 259-260.

120 Foligno 1991, 76, 78, 89-90, 95-97.

121 Pérez García 2005a, 231.

122 Serrano y Sanz 1903, 2-3.

123 Ibídem, 131.

124 Ídem.

125 AHN: I, leg. 106, n. 5. Proceso de Alcaraz, f. 163 r

126 Durante el proceso, la criada Juana Meléndez había declarado oír decir a Alcaraz «que no era menester lugar determinado para orar,
Sin duda, Alcaraz y la doctrina del dexamiento llegaron a representar una seria amenaza para el recogimiento, o al menos así lo valoraron Osuna y otros franciscanos de la provincia de Castilla. En nuestra opinión, Osuna se refería a él con ironía en el prólogo del Libro llamado Abecedario espiritual, recordándolo como un hombre que careció de los pilares de la vida espiritual:

Los que han de ser grandes contadores primero han de saber muy bien contar hasta diez y multiplicar unos pequeños números con otros, sin lo qual nunca serán contadores. Si uviesse un escalera que llegasse al cielo, como la vio Jacob, ignorante sería el que presumiesse subir sin passar primero por los más baxos escalones. De manera que ninguna cosa se alcança bien si son menospreciados sus principios, [...] Para que uno sea gran letrado, que es cosa de gran estima, claro está que nunca lo será si no aprende primero el abecé, que es la cosa más baxa que se halla. De manera que, si bien miramos, la umildad es fundamento y principio de todo, sin la qual ninguna doctrina se aprende... ${ }^{127}$

Resulta llamativo que una crítica muy parecida fuese lanzada por fray Juan de Olmillos contra Alcaraz en la deposición que hizo ante los inquisidores el 19 de diciembre de 1524 en Escalona. En nuestra opinión, este documento permite corroborar la identificación de Alcaraz con esos supuestos contadores mencionados en el prólogo del Libro Ilamado Abecedario espiritual. En aquella ocasión, Olmillos declaró haber mantenido diferentes conversaciones con Alcaraz "sobre cosas espirituales», llegando finalmente a la siguiente conclusión:

Que no era buena doctrina la quel dicho Pedro de Alcaraz les dava y enseñava, porque diz que les dezía que se dexasen al amor de Dios, qu'Él les enseñaría, e que no curasen de las cosas exteriores porque eran ataduras para no estar verdaderamente en el amor de Dios, y questo le paresçió a este testigo que era camino errado en no ponerlos en los principios que los santos enseñaron como en llorar sus pecados e tener lágrimas. ${ }^{128}$

La aprobación que el Tercer Abecedario recibió de las autoridades de la provincia de Castilla apunta de nuevo, finalmente, al triunfo de Osuna sobre Alcaraz y a la consecución de su ansiado objetivo de salvar la doctrina del recogimiento. En efecto, el ministro provincial de Castilla encargó el examen de las tres partes del Libro Ilamado Abecedario espiritual a fray Bernabé de Ávila y a fray Alfonso de la Puebla, quienes dictaminaron que «la doctrina en él contenida es católica y de mucha utilidad para los que en ella se quisieren ejercitar». Esta aprobación se imprimió después al final de las primeras ediciones de los tres primeros Abecedarios, aparecidas, como sabemos, entre 1527 y 1530. La elección de estos frailes tampoco parece casual. El primero, fray Ber-

que aunque estuviese en la plaza podía orar» (AHN: I, leg. 106, n. 5. Proceso de Alcaraz, f. 101v). El contraste con Osuna no puede ser más acusado, ya que este exhorta a orar siempre (capítulos 3 y 4 del tratado 14 del Tercer Abecedario) y trata detenidamente en el capítulo IV del tratado noveno del Tercer Abecedario sobre los lugares retirados "donde se apartan los justos a orar», trayendo para ello la autoridad de Gerson (Osuna 1998, 282-287).

127 Osuna 2004a, 125-126.

128 AHN: I, leg. 106, n. 5. Proceso de Alcaraz, f. 74r. 
nabé, guardián de San Juan de los Reyes de Toledo y carcelero de uno de los más destacados franciscanos acusados de ser maestro del dexamiento (fray Diego de Barreda), ${ }^{129}$ había sido también uno de los que atendió las quejas de Alcaraz en San Juan de los Reyes en 1524. El segundo, fray Alfonso de la Puebla, se contó entre los inquisidores que en 1529 votaron la sentencia condenatoria contra Pedro Ruiz de Alcaraz en Toledo. ${ }^{130}$ Entre tanto, el 31 de agosto de 1527 el Tercer Abecedario salió de las prensas del impresor Remón de Petras, en Toledo. Unas semanas antes, el 19 de julio, en la misma ciudad, Alcaraz entraba en la cámara del tormento del Santo Oficio para ser interrogado sobre las acusaciones que había en su contra. ${ }^{131}$

\section{CONCLUSIONES}

Desde Ros en adelante, la historiografía había venido señalando la relación existente entre la culminación del proceso de escritura y publicación del Tercer Abecedario por parte de Francisco de Osuna con el contexto problemático de los alumbrados de Toledo en la década de 1520 . No obstante, no se había precisado con la necesaria exactitud en qué medida y en qué sentido este había influido en el texto de la obra. En este artículo, a partir del estudio del recurso a la autoridad, la tradición eclesiástica, el método teológico y exegético en el conjunto del Libro llamado Abecedario espiritual, se pone de manifiesto el esfuerzo del franciscano por identificar el recogimiento con la teología mística transmitida por la tradición de la Iglesia. Todo ello permite percibir el contraste con un Alcaraz al que Osuna se refiere sin nombrarlo, que interpretaba la Biblia sin saber latín, y cuya formación en la materia se reducía a un puñado de libros de espiritualidad en romance. ${ }^{132}$ De manera particular, se

129 Pérez García 2005a, 230. Sabemos que el 9 de febrero de 1526 fray Diego de Barreda se hallaba "preso» en el monasterio de San Juan de los Reyes de Toledo. Ese día presentó una confesión ante fray Diego de Cisneros, provincial franciscano de Castilla, el maestro Quintana y Juan Ortiz de Zárate, relator de la Inquisición. En ella, Barreda no dudaba en considerar a Alcaraz, Isabel de la Cruz y Gaspar de Bedoya, los tres líderes espirituales del grupo finalmente condenado, de «muy buenos christianos e cathólicos en obras e palabras, y a esta causa holgué de comunicarme con ellos como persona a quien Jesucristo Nuestro Señor dava deseos de servirle». Entre sus afirmaciones se cuentan algunas que apuntaban de manera crítica hacia los recogidos: «yten que no buscásemos consolaciones spirituales ni temporales, mas que hiziéssemos gracias a todo lo que nos diese»; "yten que eran estatuas y piedras los que quando oravan o contemplavan dexavan de entender diciendo que desazían la naturaleza, que quando Dios viene de verdad no viene syno a perfecionarla»; y que los alumbrados «no eran amigos de arrobamientos ni de miraglos destos tiempos». Preguntado quiénes «tenían y afirmavan las opiniones contenidas en el dicho su memorial», Barreda respondió que Alcaraz, Isabel de la Cruz y Bedoya, además de él mismo, pero que habrían sido Alcaraz e Isabel de la Cruz «los primeros que a este confesante comunicaron estas cosas». El día 26 de febrero de 1526, Barreda ratificó esta declaración en presencia de fray Bernabé de Ávila, guardián del convento, y ante el relator Ortiz de Zárate, que actuaba por comisión de los inquisidores (AHN: I, leg. 106, n. 5. Proceso de Alcaraz, ff. 102r-103v). Tres años más tarde, el 14 de abril de 1529, ese mismo doctor Quintana que fue testigo de la declaración de Barreda en San Juan de los Reyes, tras haber leído los procesos y por encargo del Inquisidor general Alonso Manrique, se dirigió a este para pedirle que con Alcaraz e Isabel de la Cruz no se procediese con el rigor de la ley sino con misericordia, porque, entre otras razones, «fueron engañados por el demonio transfigurado en ángel de luz» (Márquez 1980, 240-241).

${ }_{130}$ Serrano y Sanz 1903, 128-129.

131 Descripción del tormento en Serrano y Sanz 1903, 128.

132 Márquez 1980, 109-122; Pérez García 2005a, 321-322. ha prestado atención al uso de los escritos de Jean Gerson por parte de Osuna, explicable en parte por su intención de desmontar las críticas que hacia el recogimiento y algunos franciscanos recogidos realizó el propio Alcaraz amparándose precisamente en la autoridad del canciller de la universidad de París.

\section{APÉNDICE}

TABLA 1

Autores cristianos citados expresamente en el Libro llamado Abecedario espiritual. En número de menciones

\begin{tabular}{|c|c|c|c|c|}
\hline Autor & $\begin{array}{c}\text { Primer } \\
\text { Abeceda- } \\
\text { rio }\end{array}$ & $\begin{array}{l}\text { Segundo } \\
\text { Abeceda- } \\
\text { rio }\end{array}$ & $\begin{array}{c}\text { Tercer } \\
\text { Abeceda- } \\
\text { rio }\end{array}$ & Total \\
\hline Orígenes & 3 & 3 & 1 & 7 \\
\hline San Cipriano & 3 & 9 & 10 & 22 \\
\hline $\begin{array}{l}\text { Antonio [san Antonio } \\
\text { Abad] }\end{array}$ & 0 & 0 & 1 & 1 \\
\hline Atanasio & 1 & 0 & 0 & 1 \\
\hline San Hilario & 2 & 0 & 0 & 2 \\
\hline San Ambrosio & 4 & 5 & 4 & 13 \\
\hline San Jerónimo & 5 & 17 & 15 & 37 \\
\hline San Agustín & 33 & 30 & 49 & 112 \\
\hline Gregorio Nacianceno & 0 & 0 & 2 & 2 \\
\hline San Basilio & 0 & 1 & 0 & 1 \\
\hline San Crisóstomo & 3 & 11 & 3 & 17 \\
\hline Casiano & 0 & 1 & 0 & 1 \\
\hline San Severino & 0 & 1 & 0 & 1 \\
\hline San Dionisio & 1 & 4 & 7 & 12 \\
\hline Boecio & 0 & 2 & 1 & 3 \\
\hline Casiodoro & 1 & 0 & 2 & 3 \\
\hline $\begin{array}{l}\text { San Gregorio [Magno y } \\
\text { de Nisa] }\end{array}$ & 13 & 32 & 39 & 84 \\
\hline San Isidoro & 0 & 1 & 2 & 3 \\
\hline San Juan Climaco & 0 & 0 & 1 & 1 \\
\hline El abad Isaac [de Nínive] & 0 & 0 & 4 & 4 \\
\hline Beda & 1 & 1 & 1 & 3 \\
\hline San Anselmo & 0 & 0 & 1 & 1 \\
\hline San Bernardo & 18 & 25 & 50 & 93 \\
\hline Hugo de San Víctor & 0 & 1 & 3 & 4 \\
\hline Ricardo de San Víctor & 6 & 2 & 14 & 22 \\
\hline Inocencio [III] & 0 & 1 & 0 & 1 \\
\hline San Francisco [de Asís] & 0 & 0 & 4 & 4 \\
\hline Alberto [Magno] & 0 & 1 & 0 & 1 \\
\hline San Buenaventura & 1 & 6 & 7 & 14 \\
\hline Escoto [doctor sutil] & 1 & 0 & 0 & 1 \\
\hline $\begin{array}{l}\text { Ubertino da Casale [«un } \\
\text { devoto del árbol de la } \\
\text { vida»] }\end{array}$ & 1 & 0 & 0 & 1 \\
\hline Simón de Casia & 1 & 0 & 0 & 1 \\
\hline Santa Brígida & 1 & 0 & 0 & 1 \\
\hline Gerson & 4 & 14 & 52 & 70 \\
\hline San Bernardino & 4 & 0 & 0 & 4 \\
\hline $\begin{array}{l}\text { Jan Mombaer [el } \\
\text { Roseto] }\end{array}$ & 0 & 0 & 1 & 1 \\
\hline TOTAL & 107 & 168 & 274 & 549 \\
\hline
\end{tabular}


TABLA 2

Autores paganos citados expresamente en el Libro Ilamado Abecedario espiritual. En número de menciones

\begin{tabular}{|l|c|c|c|c|}
\hline \multicolumn{1}{|c|}{ Autores } & $\begin{array}{c}\text { Primer } \\
\text { Abecedario }\end{array}$ & $\begin{array}{c}\text { Segundo } \\
\text { Abecedario }\end{array}$ & $\begin{array}{c}\text { Tercer } \\
\text { Abecedario }\end{array}$ & Total \\
\hline Platón & 0 & 3 & 0 & 3 \\
\hline Aristóteles & 4 & 2 & 3 & 9 \\
\hline Virgilio & 2 & 0 & 0 & 2 \\
\hline Séneca & 4 & 0 & 3 & 7 \\
\hline Plinio el Viejo & 1 & 0 & 0 & 1 \\
\hline $\begin{array}{l}\text { Persio [el Satí- } \\
\text { rico] }\end{array}$ & 0 & 1 & 3 & 4 \\
\hline TOTAL & 11 & 6 & 9 & 26 \\
\hline
\end{tabular}

\section{FUENTES}

Foligno, Ángela de. 1991. Libro de la vida, edición de Teodoro H. Martín. Salamanca: Ediciones Sígueme.

Osuna, Francisco de. 1537. Gracioso convite de las gracias del santo sacramento del altar. Burgos: Juan de Junta.

Osuna, Francisco de. 1550. Norte de los estados. Burgos: Juan de Junta.

Osuna, Francisco de. 1998. Tercer Abecedario Espiritual, edición de Saturnino López Santidrián. Madrid: BAC.

Osuna, Francisco de. 2002. Sexto Abecedario Espiritual. En Abecedario Espiritual V y VI partes, edición de Mariano Quirós García, vol. 3. Madrid: FUE \& Universidad Pontificia de Salamanca.

Osuna, Francisco de. 2004a. Primer Abecedario Espiritual, edición de José Juan Morcillo Pérez. Madrid: Editorial Cisneros.

Osuna, Francisco de. 2004b. Segundo Abecedario Espiritual, edición de José Juan Morcillo Pérez. Madrid: Editorial Cisneros.

Salazar, Pedro de. 1612. Corónica y Historia de la fundación y progresso de la provincia de Castilla... Madrid: Imprenta Real.

Teresa de Jesús, Santa. 1997. Libro de la vida. En Obras Completas. Madrid: BAC.

\section{BiBLIOGRAFÍA}

Álvarez Gutiérrez, Luis. 1978. El movimiento "observante» agustiniano en España y su culminación en tiempo de los Reyes Católicos. Roma: Analecta Augustiniana.

Andrés Martín, Melquiades. 1975. Los recogidos. Nueva visión de la mística española. Madrid: FUE.

Andrés Martín, Melquiades. 1977. "Los alumbrados de 1525 como reforma intermedia». Salmanticensis XXIV, 2: 307-334.

Andrés Martín, Melquiades. 1981. "Los alumbrados de Toledo en el Cuarto Abecedario Espiritual, o Ley de Amor de Francisco de Osuna (1530)». Archivo Ibero-Americano 41: 459-480.

Andrés Martín, Melquiades. 1988. "La espiritualidad franciscana en España en tiempos de las Observancias (1380-1517)». Studia historica. Historia moderna 6: 465-479.

Andrés Martín, Melquiades. 1994. Historia de la mística de la Edad de Oro en España y América. Madrid: BAC.

Bataillon, Marcel. 1966. Erasmo y España. Estudios sobre la historia espiritual del siglo XVI. México: FCE.

Bataillon, Marcel. 2000. Erasmo y el erasmismo. Barcelona: Crítica.

Beltrán de Heredia, Vicente. 1939. Historia de la reforma de la Provincia de España (1450-1550). Roma: Istituto Storico Domenicano.

Beltrán de Heredia, Vicente. 1941. Las corrientes de espiritualidad entre los dominicos de Castilla durante la primera mitad del siglo XVI. Salamanca.

Boehmer, Eduard. 1865. Franzisca Hernandez und Frai Franzisco Ortiz. Anfänge Reformatorischer Bewegungen in Spanien unter Kaiser Karl V. Leipzig: H. Haessel.

Calvert, Laura. 1973. Francisco de Osuna and the spirit of the letter. Chapel Hill: University of North Carolina.
Colombás, García M. 1955. Un reformador benedictino en tiempo de los Reyes Católicos. García Jiménez de Cisneros, abad de Montserrat. Montserrat: Abadía de Montserrat.

Combes, André. 1973. Jean Gerson commentateur dionysien. Pour I'histoire des courants doctrinaux a l'université de Paris a la fin du XIV siècle. Paris: Librairie Philosophique J. Vrin.

Crouzel, Henri. 2015. Orígenes. Un teólogo controvertido. Madrid: BAC. Drobner, Hubertus R. 2001. Manual de Patrología. Barcelona: Herder.

Garbay-Velázquez, Estelle. 2013a. "La quête du pour amour à travers la loi d'amour ou Quatrième Abécédaire spirituel de Francisco de Osuna (1530)». Revue de I'histoire des religions 230, 4: 583-608. https://doi.org/10.4000/rhr.8178

Garbay-Velázquez, Estelle. 2013b. «La circulación manuscrita de los poemas alfabéticos de Francisco de Osuna». Mélanges de la Casa de Velázquez XLIII, 2: 197-221. https://doi.org/10.4000/mcv.5271

Garbay-Velázquez, Estelle. 2018. "Quand le nom fait l'hérétique. Les mots de l'illuminisme castillan de 1525». Cahiers d'études des cultures ibériques et latino-américaines 4: 63-86. http://cecil-univ.eu/ C4_3

García Oro, José. 1980. "Conventualismo y observancia. La reforma de las órdenes religiosas en los siglos XIV y XV». En Historia de la Iglesia en España, edición de Ricardo García Villoslada, vol. III-1.․, 211-349. Madrid: BAC.

Gribomont, Jean. 1960. "La Scala Paradisi, Jean de Raïthou et Ange Clareno». Studia monastica 2: 345-358.

Groult, Pierre. 1976. Los místicos de los Países Bajos y la literatura espiritual española del siglo XVI. 2 vols. Madrid: FUE.

Illich, Iván. 2002. En el viñedo del texto. Etología de la lectura: un comentario al "Didascalicón» de Hugo de San Víctor. México: FCE.

Leclercq, Jean. 1964. «Théologie traditionnelle et théologie monastique». Irénikon 37: 50-4.

Lejarza, Fidel de. 1962. "Orígenes de la descalcez franciscana». Archivo Ibero-Americano 22: 15-131.

Lubac, Henri de. 1993. Éxégèse médiévale. Les quatre sens de l'Écriture. 4 vols. Paris: Ed. Desclée de Brouwer.

Márquez, Antonio. 1971. "Juan de Valdés, teólogo de los alumbrados». La Ciudad de Dios 184: 214-229.

Márquez, Antonio. 1980. Los alumbrados. Orígenes y filosofía (15251559). Madrid: Taurus.

Martínez Cuesta, Ángel. 1995-2015. Historia de los agustinos recoletos. 2 vols. Madrid: Editorial Augustinus.

Meseguer Fernández, Juan. 1961. «Programa de gobierno del P. Francisco de Quiñones, Ministro General O.F.M. (1523-1528)». Archivo Ibero-Americano 81: 5-51.

Musto, Ronald G. 1983. «Angelo Clareno, O.F.M.: Fourteenth-Century Translator of the Greek Fathers. An Introduction and a Checklist of Manuscripts and Printings of his Scala Paradisi». Archivum Franciscanum Historicum 76: 215-238, 589-645.

Narbona, Michel-Ange. 1910. «Ossuna et Duns Scot ou la mystique de Saint François». Études franciscaines 23: 293-311.

Nardelli Cambraia, César. 2017. «Introdução». En Livro de Isaac: edição crítica da tradução medieval portuguesa da obra de Isaac de Nínive, XIV-CIV. Belo Horizonte: Editora UFMG.

Nieto, José C. 1977a. "The Franciscan Alumbrados and the PropheticApocalyptic Tradition». The Sixteenth Century Journal 8, 3: 3-16.

Nieto, José C. 1977b. «Review. Los recogidos. Nueva visión de la mística española, by Melquiades Andrés Martín». The Sixteenth Century Journal 8, 1: 125-126.

Nieto, José C. 1979. Juan de Valdés y los orígenes de la Reforma en España e Italia. Madrid: FCE.

Nieva Ocampo, Guillermo. 2006. «La creación de la Observancia regular en el convento de San Esteban de Salamanca durante el reinado de los Reyes Católicos». Cuadernos de Historia de España 80: 91-126.

Nieva Ocampo, Guillermo. 2009. «Reformatio in membris: conventualidad y resistencia a la reforma entre los dominicos de Castilla en el siglo XV». En la España medieval 32: 297-342.

Ortega Costa de Emmart, Milagros. 1977. «Las proposiciones del Edicto de los alumbrados. Autores y calificadores». Cuadernos de investigación histórica 1: 23-36.

Ortega Costa, Milagros. 1978. Proceso de la Inquisición contra María de Cazalla. Madrid: FUE. 
Pérez García, Rafael M. 2005a. Sociología y lectura espiritual en la Castilla del Renacimiento. Madrid: FUE.

Pérez García, Rafael M. 2005b. «¿Naturaleza o Historia? Las imágenes de animales en la obra de Francisco de Osuna». En El franciscanismo en la Península Ibérica. Balance y perspectiva. I Congreso Internacional, edición de María del Mar Graña Cid, 993-1005. Barcelona: GBG Editora.

Pérez García, Rafael M. 2006a. «Pensamiento teológico y movimientos espirituales en el siglo XVI». En Historia del cristianismo, coordinación de Antonio Luis Cortés Peña, vol. III, 51-90. Madrid: Trotta \& Universidad de Granada.

Pérez García, Rafael M. 2006b. La imprenta y la literatura espiritual castellana en la España del Renacimiento. Gijón: Trea.

Pérez García, Rafael M. 2009a. «Formas interiores y exteriores de la religión en la Baja Andalucía del Renacimiento. Espiritualidad franciscana y religiosidad popular». Hispania Sacra LXI, 124: 587-620. https://doi.org/10.3989/hs.2009.v61.i124.99

Pérez García, Rafael M. 2009b. «Historia, ejemplo y virtud en la espiritualidad del Renacimiento. La cultura histórica de fray Francisco de Osuna». En Testigo del tiempo, memoria del universo. Cultura escrita y sociedad en el mundo ibérico (siglos XV-XVIII), compilado por Manuel F. Fernández, Carlos A. González y Natalia Maillard, 120-152. Barcelona: Ediciones Rubeo.

Pérez García, Rafael M. 2010. «La Biblia en la construcción del texto espiritual del Renacimiento: la historia de José, hijo de Jacob, en la obra de Francisco de Osuna». En Franciscanos, místicos, herejes y alumbrados, coordinación de Álvaro Castro Sánchez, Juan A. Egea Aranda, Rosa M. García Naranjo, Óscar Morales Pérez y Emilio J. Navarro Martínez, 153-176. Córdoba: Universidad de Córdoba \& Editorial Séneca.

Pérez García, Rafael M. 2014. «Communitas Christiana. The sources of Christian Tradition in the Construction of Early Castilian Spiritual Literature, ca. 1400-1540». En Books in the Catholic World during the early modern period, edición de Natalia Maillard Álvarez, 71113. Leiden \& Boston: Brill.

Pérez García, Rafael M. 2018. «Francisco de Osuna y Santa Teresa de Jesús. Algunas notas sobre la historia de la mística cristiana en la España del siglo XVI». e/humanista Conversos 6: 159-177.

Pérez García, Rafael M. 2019. «El argumento histórico acerca de la transmisión de la Teología Mística y la autoridad de Dionisio Areopagita en la España del siglo XVI». En Memoria de los orígenes. El discurso histórico-eclesiástico en el mundo moderno, coordinación de José Jaime García Bernal y Clara Bejarano Pellicer, 24-47. SeviIla: Editorial Universidad de Sevilla.

Quirós García, Mariano. 1997. "Los poemas abecedarios en lengua castellana de Fray Francisco de Osuna (OFM)». Castilla 22: 155177.

Quirós García, Mariano. 1998. «En torno al método del Abecedario: orígenes y evolución hasta el siglo XVI». Analecta malacitana XXI, 2: 573-599.

Ros, Fidèle de. 1936. Un maître de Sainte Thérèse. Le Père François d'Osuna. Sa vie, son oeuvre, sa doctrine spirituelle. Paris: Gabriel Beauchesne Éditeur.

Selke, Ángela. 1968. El Santo Oficio de la Inquisición. Proceso de Fr. Francisco Ortiz. Madrid: Ediciones Guadarrama.

Serrano y Sanz, Manuel. 1903. «Pedro Ruiz de Alcaraz, iluminado alcarreño del siglo XVI». Revista de Archivos, Bibliotecas y Museos 8: 1-16, 126-139.

Uribe, Ángel. 1962. "Espiritualidad de la descalcez franciscana». Archivo Ibero-Americano 22: 133-161.

Uribe, Ángel y Fidel de Lejarza. 1957. «Introducción a los orígenes de la Observancia en España. Las reformas en los siglos XIV y XV». Archivo Ibero-Americano 17.

Wilkinson, Robert J. 2007. Orientalism, Aramaic and Kabbalah in the Catholic Reformation. The First Printing of the Syriac New Testament. Leiden \& Boston: Brill. 